\title{
THE ROMANIAN ORTHODOX CHURCH \\ IN HUNGARY AND THE KINGDOM OF YUGOSLAVIA IN THE INTERWAR PERIOD
}

\author{
ALIN CRISTIAN SCRIDON \\ Faculty of Letters, History and Theology \\ West University of Timisoara, Romania \\ Bulevardul Vasile Pârvan 4, Timişoara 300223 \\ E-mail address: alin.scridon@e-uvt.ro
}

\begin{abstract}
Aim. The Romanian Orthodox Church in Hungary and Yugoslavia encountered a series of shortcomings between the two world wars. The article certifies the important role of the Church in maintaining the Romanian culture in the diaspora. This article's purpose is to make known the issues faced by Romanian communities abroad.

Methods. Our research is founded on both specialty bibliography and archive documents.

Results. Even though in our research we approach three different countries with different histories, we find that Romanian spirituality has generally encountered the same problems in the diaspora in the proximity of the country. The Romanian Patriarchate was involved in the defense of the Romanian diaspora orthodoxy. The role of the Romanian Patriarchy will be revealed in this research.

Conclusion. Regardless of the political realities of the times, the Romanians coalesced around the Romanian Orthodox Church. That is why, not by chance, the great poet Mihai Eminescu identifies the Romanian Orthodox Church with the institution that preserved the Latin element near the Danube. The activity of the Romanian Orthodox Church in Hungary and Yugoslavia in the interwar period was mainly performed by priests.

Key words: The Romanian Orthodox Church, the interwar period, Hungary, Yugoslavia.

\section{THE ROMANIAN ORTHODOX CHURCH AND THE UNITY AS A NATION IN CENTRAL EUROPE AND THE BALKAN PENINSULA. 1700-1918}

We believe that the mission of the Romanian Orthodox Church is best presented by the great Romanian poet Mihai Eminescu: „The Eastern Church has, for eighteen hundred years, been the guardian of the Latin element by the Danube. It has established and unified our language in such an admirable way that we are the only people without proper dialects; it has equally prevented us 
from being swallowed up amongst the Polish, Hungarians, Tatars and Turks, even today it is still the only defence and the only support for millions of Romanians living beyond our borders. Whoever fights it and its rituals can be considered cosmopolitan, socialist, universal republican and whatever comes to mind, but only Romanian is not" (Eminescu, 1989, p. 187).

Romanians from Serbian and Hungarian territories considered the Romanian Orthodox Church one of the most important institutions, which contributed significantly to the preservation of national identity (Bedecean, 2012, pp. 87-101). Over the centuries, the church has preserved the sacred traditions and the traditions of the ancestors. These traditions have a double meaning: religious and cultural.

Through the ministries of the Romanian churches in Yugoslavia and Hungary, the Romanian language has been cultivated and preserved unaltered. In this philological context, the significant role played by the language in the cult books used in the Church in the formation of the Romanian literary language is known (Ianeş, 1997, p. 6).

After the establishment of the Greek Catholic Bishopric and the abolition of the Orthodox Metropolitanate of Transylvania, the Orthodox Romanians entered the jurisdiction of the Metropolitan of Sremski Karlovici (1700-1864). Emperor Leopold I of Habsburg offered on 21 August 1690 church and school autonomy to all Orthodox (irrespective of ethnicity) in the empire, under the coordination of Serbian Patriarch Arsenije Čarnojević. Therefore, for almost 160 years, the Romanians in the Habsburg Empire has a Serbian bishop as their spiritual head, who, in most cases, did not speak Romanian and on whom the ordination of the Romanian priests depended. Church books in Romanian came from Wallachia (Cherciu, 2004, p. 8, 20).

The 1864 reform is known as the one by which Emperor Franz Joseph recognised the independence of the Romanian Church and the authority of the Metropolitan of Sibiu, Andrei Saguna. Through this reform, all Romanian parishes in the Habsburg territories passed under the "obedience" of the Metropolitan of Sibiu (Cherciu, 2004, pp. 30-45).

\section{THE ROMANIAN ORTHODOX CHURCH IN YUGOSLAVIA. 1918-1939}

For Romanians, the territory of Vojvodina is known by the researchers as one of the rich provinces in terms of culture. Elena Lelea, a scholar, admits that the Romanian cultural dimension is richer here than in Muntenia (Lelea, 2005, p. 3). These cultural elements were carefully preserved by the Romanian spirituality (the Romanian Orthodox Church).

After the breakup of the Habsburg Empire, the western part of Banat was incorporated into the Kingdom of the Serbs, Croats and Slovenes. In this context, the Romanian parishes remained under the jurisdiction of the two Romanian bishops of Arad and Caransebes. Historiography records 48 priests in 
40 parishes (Roşu, Negru, 2013, p. 12). Although the state authorities allowed the priests to communicate with their hierarchical chiefs, there was a significant number of expropriations of the Romanian parishes, the dissolution of the Romanian confessional schools, confiscation of the school buildings, etc. Following these abuses, a significant number of priests and believers fled to Romania (Roşu, Negru, 2013, p. 12).

In order to defend their rights in the new state reality, the Romanians established at the Alibunar (December 1931) the Association of the Orthodox Romanian Orthodox Priory in the Yugoslav Banat (Popi, 2005, p. 10).

The normalisation of the Romanian-Serbian relations came in the first stage in 1934 when the Convention on the Position of the Romanian Church in the Serbian Banat and the Serbian Orthodox Church in the Romanian Banat was concluded. The document provided for the establishment of an autonomous diocese, headed by a vicar at Vrsat, and the Orthodox Serbs in Romania would enjoy the same treatment, recognising the Romanian state of the Serbian diocese in Timisoara (Roşu, Negru, 2013, p. 12).

Unfortunately, the application of the Convention was postponed until 1971. On 28 January 1971, the Assembly of the Romanian Orthodox clergy of the Yugoslav Banat adopted the statute and chose the vicar of the Romanian diocese. The Act signed on January 28, 1971, stipulated that the 39 parishes in the Serbian Banat were grouped into three deaneries: Vrsat, Panciova and Toracu-Mic (Roşu, Negru, 2013, p. 12).

During the period to which we limited ourselves (1918-1939), there are a series of works on various Romanian Orthodox churches in Vojvodina. For example, in the town of Coştei, the present church was built between 19281940 (Roşu, Negru, 2013, p. 54). At Cuvin, the church was painted between 1937-1939. Also between these years the iconostasis was made (Rošu, Negru, 2013, p. 66). A new church was built in Deliblata in 1924 (Rošu, Negru, 2013, p. 76). A church was built between 1931-1933 and in Ovcea (Rošu, Negru, 2013, p. 229). At Doloave the fence around the church was built between 1934-1935 (Roşu, Negru, 2013, p. 89). A new fence was erected in 1923 around the church of Glogoni (Roşu, Negru, 2013, p. 110). In the Iablanca church, a new bell was mounted in 1923 (Roşu, Negru, 2013, p. 127). In 1936, Bishop Vasile Lazarescu of Caransebes visits the parish of Iabuca (Roşu, Negru, 2013, p. 134) and Omolita (Roşu, Negru, 2013, p. 213). Also in 1936 the interior of the Straja church was restored (Roşu, Negru, 2013, p. 300). A bell tower was built in Chisoroş in 1934 (Roşu, Negru, 2013, p. 255).

During the First World War, bells were seized from several Romanian churches and used to produce munitions. That is why in the interwar period the communities endeavored to buy new bells. For example, new bells have been received by the churches of Mărghita, Mesici, Omolița, Seleuş, Romanian Sack, Toracu-Mare, Uzdin, Vladimirovăt, Vlaicovăț etc.

Thus, the spiritual life of the Orthodox Romanians in interwar Yugoslavia was a dynamic one. Despite the political realities of those times, the Romanian Orthodox Church was able to operate in Yugoslav territory. 
ROMANIAN ORTHODOX CHURCH IN HUNGARY. 1918-1939

One of the most challenging phases in the history of the Orthodox Romanians in Hungary was undoubtedly during Miklós Horthy's takeover of political power. Miklós Horthy was voted in by Hungarian lawmakers on 1 March 1920 (Scridon, 2016, p. 592).

After the end of the First World War and the drawing of the borders between Hungary and Romania, 17 Romanian Orthodox parishes remained in Hungary. The 17 parishes were canonically dependant, until 1920, on the bishops of Oradea and Arad. Since 1920, the Diocese of Arad, as well as the Romanian Orthodox Vicar of Oradea have been unable to coordinate efficiently the Romanian parishes in Hungarian space. The church policy of the Budapest government to suppress the Romanian spirituality in eastern Hungary was clear. The 17 parishes were coordinated by only four priests. The lack of priests from the Romanian parishes in Hungary caused a series of disturbances in the Romanian communities. The service was held in Romanian, and the lack of service was a step in the process of denationalisation. Attracting graduate theologians from Romania to occupy parishes in Hungary was hindered by the Hungarian authorities. The only solution Romanians had in Hungary was the schooling in the Theology academies of young Romanians, but Hungarian citizens. Historiography records a small number of locals who followed theology (Scridon, 2016, p. 592-600).

The suppression of the ministry in the Romanian Orthodox churches in Hungary was one of the plans of the Budapest government. Another plan, obviously with a utopian perspective, made by Miklós Horthy was the establishment of the Hungarian Orthodox Church (BOM) and the Faculty of Orthodox Theology, teaching exclusively in Hungarian.

The Faculty of Orthodox Theology in Budapest had one of the shortest lives in the history of European religious education. It was established in 1942 and was abolished two years later in 1944 (Misaroş, 2002, p. 248-249).

The BOM was then to be raised to the rank of patriarchy, which would have subordinated some metropolises. The utopia is evident through the fact that the Hungarians are either Catholic or Protestant. The BOM was coordinated by the ministry of cults in Budapest and therefore targeted the minorities (Romanians, Serbs, Greeks). As a result, the Budapest government interfered with church minority affairs in the country.

Until the establishment of the BOM (April 12, 1942), the Orthodox communities in Hungary tried to maintain ties with the patriarchs in the countries of origin. After the Second World War the BOM was abolished and the Orthodox Romanians enjoyed in 1946 the establishment of the Romanian Orthodox Vicar of Hungary (Misaroş, 2002, p. 252).

So the Romanian Orthodox Church in Hungary in the interwar period had a difficult mission, namely the struggle for survival. The issue of the disappearance of the Romanian Church in Hungary was a reality that today remains a history page. 


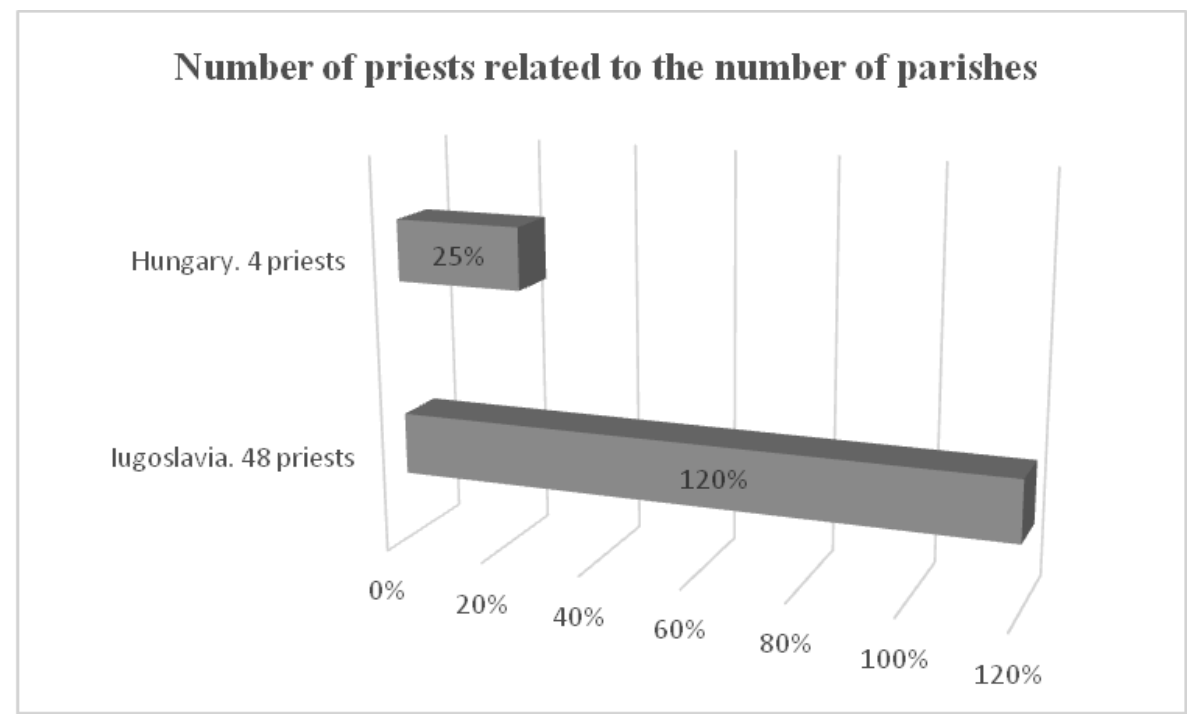

Graph 1. Number of priests related to the number of parishes.

Source: Misaroş, 2002; Roşu, Negru, 2013

\section{CONCLUSIONS}

Today, as in the interwar period, Romania is the only country in Europe surrounded by fellow countrymen who are called Romanians, Vlachs, Moldavians, Aromanians, Macedonians and are, in compact groups, from countries such as: the Russian Federation, the Republic of Moldova, Ukraine, Hungary, Slovakia, Albania, Bulgaria, Greece and the former Yugoslavia.

Regardless of the political realities of the times, the Romanians coalesced around the Romanian Orthodox Church. That is why, not by chance, the great poet Mihai Eminescu identifies the Romanian Orthodox Church with the institution that preserved the Latin element near the Danube.

The activity of the Romanian Orthodox Church in Hungary and Yugoslavia in the interwar period was mainly performed by priests. The chart above illustrates how the authorities have let Romanian spirituality unfold.

\section{REFERENCES}

1. Bedecean, M. (2012). Separația ierarhică în Eparhia Vârşeț, studii de caz [Hierarchical separation in the Vrsac Diocese, case studies]. In: Gh. Popovici, C. Albert (Eds.), Studii şi cercetări, Banatul, istorie şi multiculturalitate [Studies and Research, Banat, History and Multiculturalism] (pp. 87-101). Reşița, Romania: Eftimie Murgu University Publishing House.

2. Cherciu, V. D. (2004). Biserica în modernitate. Episcopia Ortodoxă de Caransebeş (1865-1889) [The Church in Modernity, Orthodox Bishopric of Caransebes, 1865-1889]. Timişoara, Romania: Marineasa Publishing House.

3. Eminescu, M. (1989). Liber-cugetător, liberă-cugetare [Free-thinker, free-thinking]. Opere, X, 187-188. 
4. Ianeş, M. (1997). Păstrându-ne Biserica ne păstrăm identitatea [By keeping our Church we keep our identity], Traditia, 8 (11), 6-7.

5. Lelea, E. (2005). Cuvânt înainte [Foreword]. In: Gh. Vulcu Pleşu (Ed.), Monografia satului Sălcița [The monograph of the Sălcița village], (pp. 3-5),Vârşeț Serbia: COBISS.

6. Misaroş, T. (2002). Din istoria comunităților bisericeşti ortodoxe române din Ungaria [From the history of the Romanian Orthodox churches in Hungary]. Second Edition, revised. Gyula, Ungaria: NKÖM.

7. Popi, G. (2005). Prima asociație a clerului român din Banatul iugoslav [The First Association of the Romanian Clergy of the Yugoslav Banat]. Dealul Vârşetului, 3, 8-10.

8. Roşu, C., Negru, A. (2013). Bisericile Ortodoxe Româneşti din Banatul sârbesc [Romanian Orthodox Churches in the Serbian Banat]. Novi Sad, Serbia: Romanian Orthodox Churches in the Serbian Banat.

9. Scridon, A. C. (2016). Elite româneşti din Ungaria în timpul lui Miklós Horthy şi şcolarizarea lor in institutele teologice ortodoxe din România [Romanian Elite in Hungary during Miklós Horthy and their schooling in Orthodox theological institutes in Romania]. In: D. Alic (Ed.), Slujire şi educație [Service and education] (pp. 592-600), Cluj-Napoca, România: Presa Universitară Clujeană - Editura Episcopiei Caransebeşului. 